\title{
AZ ORVOSI HIÁBAVALÓSÁGRÓL
}

Magyarul az Orvosi hiábavalóság a gyermekgyógyászatban: Interdiszciplináris és nemzetközi perspektivák címü könyvet a budapesti székhelyü Trivent Publishing adta ki. A Trivent 1993-ban rendezvényszervező vállalkozásként indult, majd az évek során megszerzett tapasztalataival tett szert a tudományos publikáláshoz szükséges szakértelemre. Indulása óta számos, tudományos szempontból is színvonalas kötetet, könyvsorozatot és folyóiratot publikált.

Az ismertetett könyvet Kartina A. Choong szerkesztette, aki a brit School of Law and Science kutatója, és aki rendelkezik a szükséges jogi, orvosjogi, orvosetikai, gazdasági ismeretekkel, sőt, az iszlám tanulmányokban is jártas. Az egyes fejezetek szerzői között találunk jogászt, orvost, bioetikust és teológust. A mü két nagy egységre tagolódik. Az első rész (1-9. fejezet) az orvosi hiábavalóság interdiszciplináris elemzését tartalmazza, a második rész (10-16. fejezet) pedig különböző országok gyakorlatát mutatja be.

A bevezetés Charlie Gard és Alfie Evans esetét mutatja be, betegségük felfedezésétől (2016) a bírósági procedúrákon keresztül egészen a két gyermek haláláig (2018). Az orvoscsoportok szakvéleménye szerint a gyermekek állapota olyanynyira súlyos és visszafordíthatatlan, hogy az életfenntartó kezelések visszavonását támogatják, szem előtt tartva a gyermekek méltóságát. Ezt a szülők nem képesek elfogadni, ezért a bírósághoz fordulnak. Nyilvánvaló, hogy nem a tárgyalóterem a legalkalmasabb fórum az ilyen esetek kezelésére. Már a bevezető esetek alapján is felmerül a kérdés, hogy a szülői jogokat meddig kell védeni? A mü rámutat arra is, hogy az orvosi hiábavalóság kérdése különösen súlyos problémát jelent a gyermekek esetében. Mivel a gyerekek akarata nem érvényesülhet, ezért helyettesek (szülők, gyám, orvosok, bíróság) döntenek helyettük, ami konfliktusokat generálhat.

Az első részben találkozhatunk azokkal az alapvető konfliktusokkal, fogalmakkal és definíciókkal, amelyek tárgyalása és tárgyalásainak nehézségei végigkísérik a müvet. A kulcsfogalom az orvosi hasztalanság, ez olyan tevékenységre utal, amely értelmetlen, vagy amelynek nincs hatékony elönye és haszna a beteg számára (5.). Emellett fontos fogalom a gyermek legjobb érdeke (Child's Best Interests, továbbiakban: BI). Világos, hogy egyik fogalomnak sincs pontos meghatározása. Szintén fontos kérdés a szülők és az orvosok között fennálló vita, és annak rendezési lehetősége.

Az első fejezet a BI-teszt evolúciós vizsgálatára helyezi a hangsúlyt, s már itt is megjelenik a mediáció mint vitarendezési eszköz. Vannak, akik a BI-megközelités védelmére kelnek (lásd 2. fejezet), mások pedig vitatják azt, hogy aranystandardként (Gold Standard) alkalmazzuk (lásd 3. fejezet). Ez az elméleti vita kiegészül a jelentős kár (Significant Harm) fogalmával is. 
A negyedik fejezetben kerül górcső alá a mediáció, vagyis a közvetítés fontossága (Media Framing of 'Medical Futility': Flaming the Debate?). A szerző ezt a bírósági eljárások helyett vagy legalább azt megelőző humánus tárgyalási eszközként javasolja. A fejezet szerzője elemezve a média szerepét és lehetséges hatásait, annak negatív oldalára is rámutat. A média bevonása a vitás esetek rendezésébe azért veszélyes, mert így megjelenhet a torzítás, az információ-visszatartás és a részrehajlás. Ehelyett éppen a nyilvánosságtól mentesen, részrehajlás nélkül, minden oldalt meghallgatva kell fórumot teremteni a vitás helyzetek rendezésére. Ennek szándékával kerül bemutatásra és elemzésre a mediáció. Jellemzője, hogy a konfliktusban részt vevő szereplőknek megteremti azt a semleges környezetet, amelyben mindegyik fél objektíven és szándékának megfelelően meg tudja osztani a másikkal véleményét, kívánságát, álláspontját. A mediátor szerepe itt az, hogy megtörve a kommunikációs zavart a felek között, azok egymást megértve közösen konszenzusra jussanak, ami nemcsak pénzügyi, hanem testi-lelki szempontból is kisebb terhet jelent.

A további fejezetekben találkozhatunk erőforrás-menedzsmentre (5. fejezet), állampolgári kérdésekre (6. fejezet), az anglikán egyház orvosetikai döntéshozatali folyamataira (7. fejezet), az iszlám jogi megközelítésre (8. fejezet) irányuló elemzéssel. Az első rész utolsó fejezete (9. fejezet) azt vizsgálja, hogy a szülők hazavihetik-e a haldokló gyermeküket.

A könyv második egysége a nemzetközi perspektívákat elemzi. Itt számos ország (Ausztrália, Cseh-, Francia-, Német-, Törökország, India és az Egyesült Államok) gyakorlatát ismerheti meg az olvasó. Ez a szakasz egyfajta példatárként is használható. Ez a rész is szervesen kapcsolódik a kiinduló témához, az orvosi haszontalanság problémájához.

Összességében elmondható, hogy a könyv az orvosi haszontalanságot vizsgálja a gyermek legjobb érdekeinek középpontba állításával. Nemcsak az időben felajánlott mediációra és annak fontosságára, hasznosságára hívja fel a figyelmet, hanem arra is, hogy a szülői jogokra (melyek nem abszolútak) és kötelességekre miként kell tekinteni, és milyen mértékben lehet és szükséges védeni azokat. A könyv kettős szerkezete kiváló lehetőséget kínál egy átfogó, elméleti alapokat teremtő és tárgyaló ismeretterjesztésre, valamint a különböző országok joggyakorlatának a megismerésére.

(Kartina A. Choong editor: Medical Futility in Paediatrics: Interdisciplinary and International Perspectives, Budapest: TRIVENT Publishing, 2019, 329 o.)

Laki Beáta

PhD, Pécsi Tudományegyetem Általános Orvostudományi Kar Magatartástudományi Intézet 